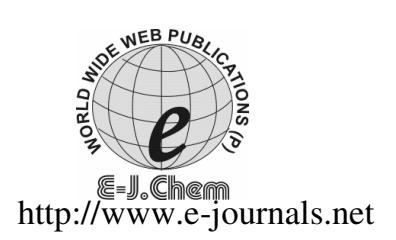

ISSN: 0973-4945; CODEN ECJHAO

E-Journal of Chemistry

2011, 8(3), 1038-1043

\title{
Synthesis of Poly(hydroxamic Acid)-Poly(amidoxime) Chelating Ligands for Removal of Metals from Industrial Wastewater
}

\author{
M. R. LUTFOR ${ }^{*}$ and M.Y. MASHITAH \\ Faculty of Industrials Sciences and Technology \\ University Malaysia Pahang, 26300 Gambang, Kuantan, Pahang, Malaysia \\ lutfor73@gmail.com
}

Received 6 September 2010; Accepted 22 November 2010

\begin{abstract}
Synthesis of poly(hydroxamic acid)-poly(amidoxime) chelating ligands were carried out from poly(methyl acrylate-co-acrylonitrile) grafted sago starch and hydroxylamine in alkaline medium. The binding property of metal ions was performed and maximum sorption capacity of the copper was $3.20 \mathrm{mmol} / \mathrm{g}$ and the rate of exchange of some metals was faster, i.e. $\mathrm{t}_{1 / 2} \approx 7 \mathrm{~min}$ (average). Two types of wastewater containing chromium, zinc, nickel, copper and iron, etc. were used and the heavy metal recovery was found to be highly efficient, about $99 \%$ of the metals could be removed from the metal plating wastewater.
\end{abstract}

Keywords: Absorption, Heavy metals, Plating wastewater, Polymeric chelating ligands

\section{Introduction}

Environmental contamination with heavy metals has been a potential threat to humans and animals and such metals do not undergo biodegradation. Removal of heavy metals from waste streams employs various technologies, which are often either expensive or inefficient, especially when very low residual concentrations in the wastewater. Heavy metals contamination in aqueous wastes from various industries, such as metal plating, mining operations, tanneries, chloro alkali, radiator manufacturing, smelting, alloy and storage battery industries ${ }^{1}$. Heavy metals do not degrade easily into harmless end products and due to their high toxicity heavy metal-containing industrial wastewaters must be treated before being discharged into the environment ${ }^{2}$.

Several measures are taken to prevent environment pollution, such as precipitation, adsorption and ion exchange and reverse osmosis to remove heavy metals ${ }^{3}$. At present precipitation is the most applicable of the current techniques available and is also considered to be the most economical. Chemical coagulation occurs by adding lime to raise the $\mathrm{pH}$, thus 
inducing precipitation, followed by the addition of activated silica or polyelectrolytes to stimulate coagulation. Several researchers have reported that electro-coagulation could be used to remove heavy metals from solutions ${ }^{4,5}$.

In some cases, wastewater treatment by precipitation may be followed by adsorption onto activated carbon to remove the metals at the highest level. Although known to be quite effective in treating industrial effluents, chemical coagulation induces secondary pollution due to the addition of chemicals. Heavy metal precipitation also produces intractable sludge that must be treated and disposed of often at high cost ${ }^{6}$. Therefore the need for an effective methodology to overcome this drawback is essential to treat industrial effluents.

Heavy metal removal from the effluent with acceptable concentrations is the aim of this study. Therefore, a polymeric chelating ligand containing hydroxamic acid and amidoxime ligands was synthesized from poly(methyl acrylate-co-acrylonitrile) grafted sago starch. The chelating behavior of the prepared ligands in response to a series of heavy metals was investigated using batch techniques. In addition, heavy metals were removed from wastewaters by these ligands carried out using column technique.

\section{Experimental}

The poly(methyl acrylate-co-acrylonitrile) grafted sago starch (PMA-co-PAN) were prepared according to the procedure described in an earlier paper ${ }^{7}$. Commercial available metal sulfate/ nitrate of analytical reagent grade were used in this study. The standard solution of metals (1000 mg/L) was obtained from Perkin Elmer.

Two types of plating wastewaters were collected from BI-PMB Waste Management Sdn. Bhd, Shah Alam, Kuala Lumpur (Malaysia): chromium plating wastewater (Cr-wastewater) and cyanide process wastewater ( $\mathrm{CN}$-wastewater). Both wastewaters were adjusted to $\mathrm{pH} 4$ using acid/alkali $(\mathrm{HCl} / \mathrm{NaOH})$ solutions and analyzed by ICP-OES (Perkin Elmer Optima 5300 DV). All metal ions concentrations were presented in Table 1.

Table 1. Heavy metal concentration in the wastewater test at $\mathrm{pH} 4$

\begin{tabular}{ccc}
\hline \multirow{2}{*}{ Metal Ions } & \multicolumn{2}{c}{ Concentration of metal ions, mg/ L } \\
\cline { 2 - 3 } & Cr-wastewater & CN-wastewater \\
\hline $\mathrm{Cu}$ & $2.301( \pm 0.05)$ & $6.156( \pm 0.25)$ \\
$\mathrm{Co}$ & $0.079( \pm 0.15)$ & $0.188( \pm 0.06)$ \\
$\mathrm{Cr}$ & $27.43( \pm 0.08)$ & $2.051( \pm 0.16)$ \\
$\mathrm{Mn}$ & $0.103( \pm 0.04)$ & $0.396( \pm 0.08)$ \\
$\mathrm{Fe}$ & $1.901( \pm 0.09)$ & $9.651( \pm 0.25)$ \\
$\mathrm{Ni}$ & $6.123( \pm 0.18)$ & $33.16( \pm 0.48)$ \\
$\mathrm{Zn}$ & $4.793( \pm 0.24)$ & $44.44( \pm 0.55)$ \\
$\mathrm{Pb}$ & $0.110( \pm 0.02)$ & $0.106( \pm 0.04)$ \\
$\mathrm{Cd}$ & $0.242( \pm 0.07)$ & $0.068( \pm 0.03)$ \\
\hline
\end{tabular}

\section{Preparation of poly(hydroxamic acid)-poly(amidoxime) chelating ligands}

Preparation of hydroxylamine solution $\left(\mathrm{NH}_{2} \mathrm{OH}\right)$

About $21.00 \mathrm{~g}$ of hydroxylamine hydrochloride $\left(\mathrm{NH}_{2} \mathrm{OH} . \mathrm{HCl}\right)$ was dissolved in $150 \mathrm{~mL}$ methanolic solution (methanol: water / 5: 1). The $\mathrm{HCl}$ was neutralized by $\mathrm{NaOH}$ solution and the precipitated $\mathrm{NaCl}$ was removed by filtration. The $\mathrm{pH}$ of the reaction solution was adjusted to $\mathrm{pH} 12$ by addition of $\mathrm{NaOH}$ solution. The reaction medium was maintain at a methanol to water ratio of $5: 1$. 
A double neck flask $500 \mathrm{~mL}$ size was fitted with a condenser and immerse in a thermostat water bath. About $10.00 \mathrm{~g}$ of PMA-co-PAN grafted sago starch was placed in the flask and the hydroxylamine solution is added to the flask. The reaction was carried out at $70{ }^{\circ} \mathrm{C}$ for $2 \mathrm{~h}$. The products were separated from solution by filtration and washed several times with methanolic solution (methanol: water/ 5: 1). The ligands were treated with $100 \mathrm{~mL}$ of methanolic $\mathrm{HCl}$ solution $(0.2 \mathrm{M})$ for $5 \mathrm{~min}$ and washed several times with methanolic solution (methanol : water/ $5: 1$ ). The product was dried in oven at $50{ }^{\circ} \mathrm{C}$ to a constant weight and screening the ligands bead approximate size 100-200 $\mu \mathrm{m}$.

The structure of PMA-co-PAN grafted sago at upper and the structure of poly(hydroxamic acid)-poly(amidoxime) ligands at lower (ST is the sago starch, $\mathrm{H}$ hydroxamic acid and A amidoxime ligand) is shown in Scheme 1.

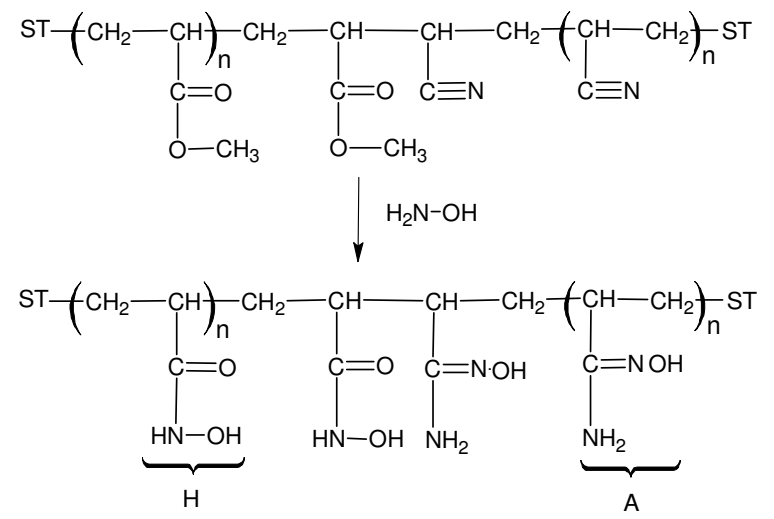

Scheme 1. Reagents and conditions: PMA-co-PAN grafted copolymer and hydroxylamine ratio, 1: $1 ; \mathrm{pH} 12$, temperature $72{ }^{\circ} \mathrm{C}$, reaction period $2 \mathrm{~h} .0 .2 \mathrm{M}$ metal solution for complex.

\section{Sorption of metals by batch technique}

The dry ligands exactly $0.2000 \mathrm{~g}$ were allowed to equilibrate with $20 \mathrm{~mL}$ distilled water for $30 \mathrm{~min}$ and $10 \mathrm{~mL}$ of $0.1 \mathrm{M}$ sodium acetate buffer solution was added at differing $\mathrm{pH}$, About 20 minutes later $10 \mathrm{~mL}$ of $0.1 \mathrm{M}$ metal ion solution was added and the mixtures were shaken for $6 \mathrm{~h}$ using a rotary shaker. The amount of metal ion uptake was determined from the difference in concentrations at the beginning and end of the batch test. All experiment was carried out in replicated for appropriate absorption capacity. The amount of metal sorption in the sample was calculated using Equation 1.

$$
\mathrm{q}_{\mathrm{e}}=\frac{\left(\mathrm{C}_{0}-\mathrm{C}_{\mathrm{e}}\right) \mathrm{V}}{\mathrm{L}} \times \frac{1}{\mathrm{M}}
$$

Where $\mathrm{q}_{\mathrm{e}}$ is the equilibrium sorption amount $(\mathrm{mmol} / \mathrm{g}), \mathrm{C}_{0}$ is the initial concentration of metal solution $(\mathrm{mg} / \mathrm{L}), \mathrm{C}_{\mathrm{e}}$ is the equilibrium concentration of metal $(\mathrm{mg} / \mathrm{L}), \mathrm{V}$ is the volume of metal solution (L), L is mass of the polymeric ligands $(\mathrm{g})$ and $\mathrm{M}$ is the mol weight of the specific metal.

\section{Sorption kinetics by batch technique}

The rate of exchange of heavy metals in the acetate buffer at $\mathrm{pH} 6$ was determined by $0.2000 \mathrm{~g}$ of ligand beads in $10 \mathrm{~mL}$ of $0.1 \mathrm{M}$ metal solution for various time intervals such as $2,5,10,20,30$ and 60 minutes. The residual metal concentration was determined by ICP and the sorption amount was calculated according to Equation 2. 


$$
\mathrm{q}_{\mathrm{t}}=\frac{\left(\mathrm{C}_{0}-\mathrm{C}_{\mathrm{t}}\right) \mathrm{V}}{\mathrm{L}} \times \frac{1}{\mathrm{M}}
$$

Where $\mathrm{q}_{\mathrm{t}}$ is the sorption amount at time $\mathrm{t}(\mathrm{mmol} / \mathrm{g}), \mathrm{C}_{0}$ is the initial concentration of metal solution $(\mathrm{mg} / \mathrm{L}), \mathrm{C}_{\mathrm{t}}(\mathrm{mg} / \mathrm{L})$ is metal concentration at time $\mathrm{t}, \mathrm{V}$ is the volume of metal solution (L), $\mathrm{L}$ is the mass of polymeric ligands $(\mathrm{g})$ and $\mathrm{M}$ is the mol weight of the specific metal.

\section{Extraction of metals by column packing technique}

The slurry of PHA-PA ligands (4.0 g) was mixed with buffer at $\mathrm{pH} 4$ and was packed in glass columns. Metal ion solutions of specific wastewater ( $c f$. Table 1) were then allowed to percolate through each column at a flow rate of $5.0 \mathrm{~mL} / \mathrm{min}$. Samples were collected at the column outlet until the column reached saturation, followed by analysis using ICP-OES. The column operation was performed with replicated experiment to ensure appropriate percent extraction of metal ions from wastewaters.

\section{Results and Discussion}

\section{Synthesis of poly(hydroxamic acid)-poly(amidoxime) chelating ligands}

A polymeric chelating ligand containing hydroxamic acid and amidoxime ligands was synthesized from poly(methyl acrylate-co-acrylonitrile) grafted sago starch under alkaline solution. The structure of poly(hydroxamic acid)-poly(amidoxime) ligands at upper ( $\mathrm{H}$ is the hydroxamic acid and A amidoxime ligand). The structure of the hydroxamic acidamidoxime chelate complex with heavy metals is also shown in Scheme 2.

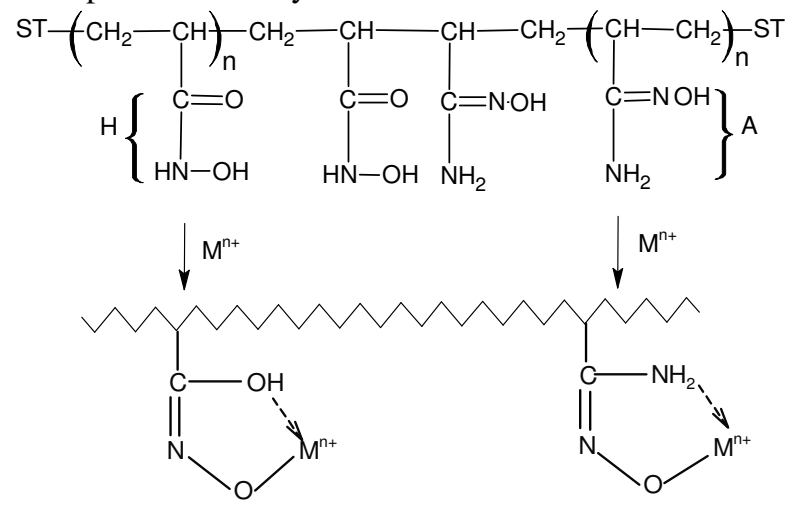

Scheme 2. Chelating complex of metal ions of five members ring hydroxamic acid (left) and amidoxime (right)

\section{Sorption of metals by batch technique}

A series of heavy metals was binding with the ligands (PHA-PA) using sodium acetate buffer solution from $\mathrm{pH} 3$ to 6 . The relative amount of metal ion taken up by the ligands steadily increased, with $\mathrm{pH}$ increase up to 6 . The ligands exhibit a high affinity for copper (3.2 mmol/g) and other metals also have significance binding capacity such as iron, zinc, chromium, nickel, cobalt and cadmium has 2.80, 2.30, 2.10, 2.0, 1.75 and $1.57 \mathrm{mmol} / \mathrm{g}$, respectively at $\mathrm{pH} 6$, but less binding capacity for lead (Figure 1). It was found that the sorption capacities are $\mathrm{pH}$ dependent. The binding capacity with this ligand is the following order: $\mathrm{Cu}^{2+}>\mathrm{Fe}^{3+}>\mathrm{Zn}^{2+}>\mathrm{Cr}^{3+}>\mathrm{Ni}^{2+}>\mathrm{Co}^{2+}>\mathrm{Cd}^{2+}>\mathrm{Pb}^{2+}$. Thus, these ligands can be used to remove metal ions from wastewater collected from plating industries. 


\section{Sorption kinetic by batch technique}

The sorption rate of metals was carried out using a buffer solution at $\mathrm{pH} 6$. The time required for $50 \%$ exchange $\left(\mathrm{t}_{1 / 2}\right)$ was calculated from the plot of the metal sorption capacity $(\mathrm{mmol} / \mathrm{g})$ vs time (Figure 2). The sorption rate of metals was very fast, i.e. $\mathrm{t}_{1 / 2}$ for $\mathrm{Cu}, \mathrm{Fe}, \mathrm{Ni}, \mathrm{Zn}, \mathrm{Cr}, \mathrm{Co}, \mathrm{Cd}$ and $\mathrm{Pb}$ were 5, 5, 5, 7, $6,8,12$ and 15 minutes, respectively. These ligands have the advantage of a faster rate of equilibrium; therefore, the column technique would be most efficient for heavy metal extraction.

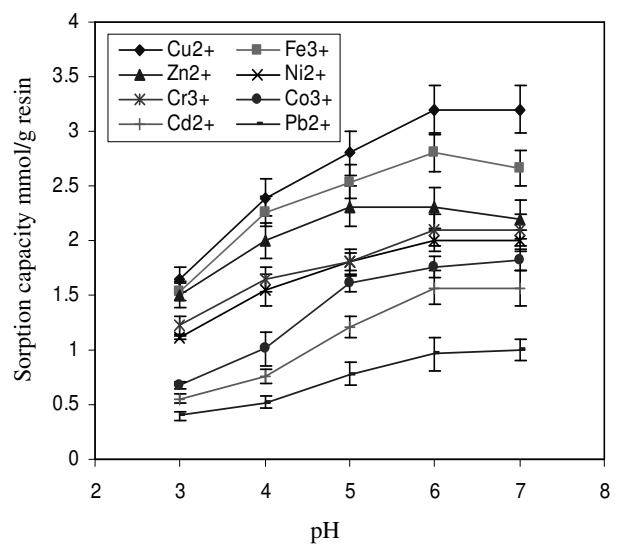

Figure 1. Heavy metals sorption capacity by the ligands as a function of $\mathrm{pH}$

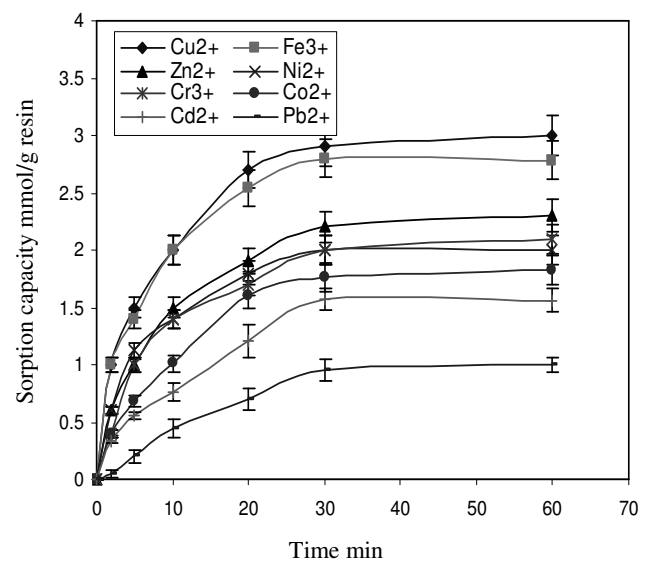

Figure 2. Rate of exchange of heavy metals by the ligands at $\mathrm{pH} 6$

\section{Extraction of metals by column technique}

Two types of wastewaters such as chromium wastewater and cyanide wastewater obtained from metal plating industries having major heavy metals like $\mathrm{Cu}, \mathrm{Cr}, \mathrm{Fe}, \mathrm{Ni}$ and $\mathrm{Zn}$ ( $c f$. Table 1). The ligands were conditioned with buffer $\mathrm{pH} 4$ and packed into the column. Each type of wastewater was poured into the column for metal recovery.

\section{Chromium wastewater}

The chromium plating process wastewater was analyzed by ICP and some metals, such as $\mathrm{Cu}, \mathrm{Ni}, \mathrm{Cr}, \mathrm{Fe}$ and $\mathrm{Zn}$, showed higher concentrations ( $c f$.Table 1). The chromium wastewater was adjusted to $\mathrm{pH} 4$ for suitable metal extraction using the column technique and the flow rate is easily adjustable at $\mathrm{pH}$ 4. The metal removal, $\mathrm{Cr}$ extraction, was $99.0 \%$ at $\mathrm{Cr}$ concentration of $27.43 \mathrm{mg} / \mathrm{L}$ (Figure 3). Other heavy metals, such as $\mathrm{Cu}, \mathrm{Co}, \mathrm{Mn}, \mathrm{Fe}$, $\mathrm{Ni}, \mathrm{Zn}, \mathrm{Pb}$ and $\mathrm{Cd}$ extraction, were 99.0, 99.1, 99.6, 94.0, 94.0, 90.0, 80.2 and 88.1\%, respectively. Thus overall heavy metal extraction is excellent by this ligands.

\section{Cyanide wastewater}

The cyanide wastewater was adjusted to $\mathrm{pH} 4$ for metal extraction. Thus, the metal ions removal, $\mathrm{Ni}$ and $\mathrm{Zn}$ extractions, was 94.0 and $88.1 \%$, respectively, when the concentrations of $\mathrm{Ni}$ and $\mathrm{Zn}$ were 33.16 and $44.44 \mathrm{mg} / \mathrm{L}$, respectively (Figure 3). Although the initial concentrations of $\mathrm{Ni}$ and $\mathrm{Zn}$ were higher, better removal was found on using the ligands. The extractions of other metals like $\mathrm{Cu}, \mathrm{Co}, \mathrm{Cr}, \mathrm{Mn}, \mathrm{Fe}, \mathrm{Pb}$ and $\mathrm{Cd}$ were 99.4, 99.6, 96.0, 95.0, 92.0, 92.1 and 93.2\%, respectively. Overall, the extraction of heavy metal was very good from cyanide wastewater.

NCP (Neurospora crassa gene expressed in the periplasmic space) removed heavy metals from solutions containing heavy metals ${ }^{6}$. Three process wastewater streams such as acid/alkali, chromate and cyanide were tested and NCP was noted to be removing the heavy metals from 
wastewaters at near neutral $\mathrm{pH}$. Macrocyclic ligands were reported in static sorption studies to show preference for the cations of noble metals like gold, silver, platinum and palladium over other metal cations including copper, lead and cadmium ${ }^{8}$. Two chelating resins were synthesized incorporating imidazolylazobenzene and 1,4-bis(imidazolylazo) benzene as the functional group into the Merrifield polymer'. Cadmium was reported to be removed from water having the normal $\mathrm{pH}$ of natural water. However, no clear evidence of percent extraction of heavy metals at low concentration in wastewater using the column technique was reported.

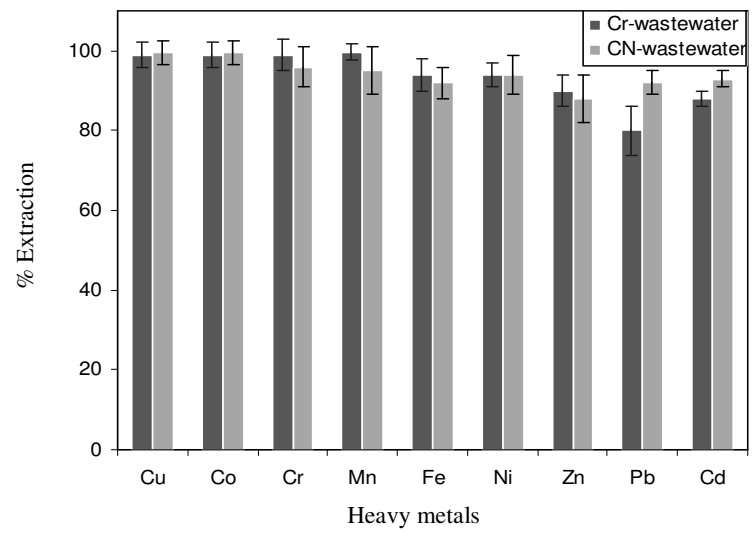

Figure 3. Heavy metal removal from chromium, cyanide and acid/alkali wastewater by PHA-PA ligands, Column condition: Column bed $20 \mathrm{~cm}$, conditioned at $\mathrm{pH} \mathrm{4}$, diameter of glass column $20 \mathrm{~mm}$, flow rate $5 \mathrm{~mL} / \mathrm{min}$.

\section{Conclusion}

The binding property of some metal ions with the ligands was good at $\mathrm{pH}$. Two types of wastewater containing heavy metals were used in the column operation and metal recovery was found highly efficient, about $99 \%$ of metals could be removed from the metal plating effluents. As high-affinity chelating polymeric ligands work in the presence of alkali metals, they are highly desirable in waste treatment. Metal removal by the PHA-PA chelating ligands system shows considerable promise in achieving this goal. Its selectivity suggests that it may be possible to recover heavy metals efficiently from wastewater. Further study is in progress to optimize metal binding and extraction performance in a column.

\section{Acknowledgment}

This research was supported by Science fund (No: SCF0011-IND-2006) from the Ministry of Science, Technology and Innovation of Malaysia and International Foundation for Science (No: W/3431-1, Sweden).

\section{References}

1. Kadirvelu K, Thamaraiselvi K and Namasivayam C, Bioresour Technol., 2001, 76, 63-65.

2. $\quad$ Gupta V K, Gupta M and Sharma S, Water Res., 2001, 35(5), 1125-1134.

3. Wilkins E and Yang Q J, Environ Sci Health A., 1996, 31, 2111.

4. Kumar P R, Chaudhari S, Khilar K C and Mahajan S P, Chemosphere, 2004, 55(9), $1245-1252$.

$5 \quad$ Narayanan N V and Mahesh G, J Hazar Mater, 2009, 161(1), 575-580.

6. Brower J B, Ryan R L and Pazirandeh M, Environ Sci Technol., 1997, 31, 2910-2914.

7. Lutfor M R, Silong S, Wan Yunus W M Z, Rahman M Z A, Ahmad M and Haron J, J Appl Polym Sci, 2001, 79(7), 1256-1264.

8. Kaledkowski A and Trochimczuk A W, Sep Sci Tech., 2006, 41, 3431-3447.

9. Pramanik S, Sanjoy D, Shuvendu S B and Pabitra C, Anal Chim Acta, 2006, 556, 430-437. 


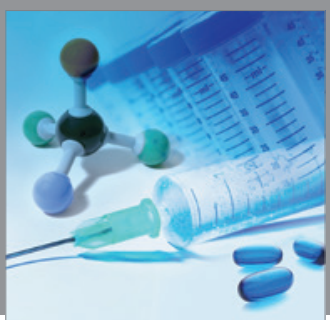

International Journal of

Medicinal Chemistry

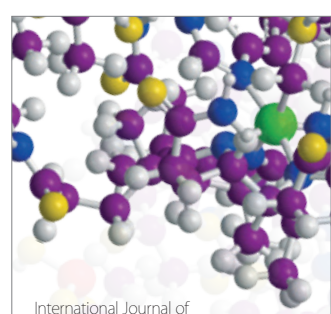

Carbohydrate Chemistry

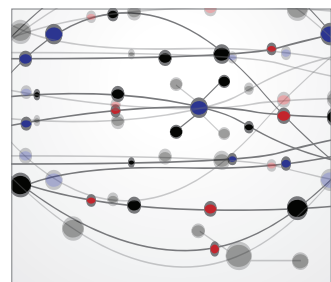

The Scientific World Journal
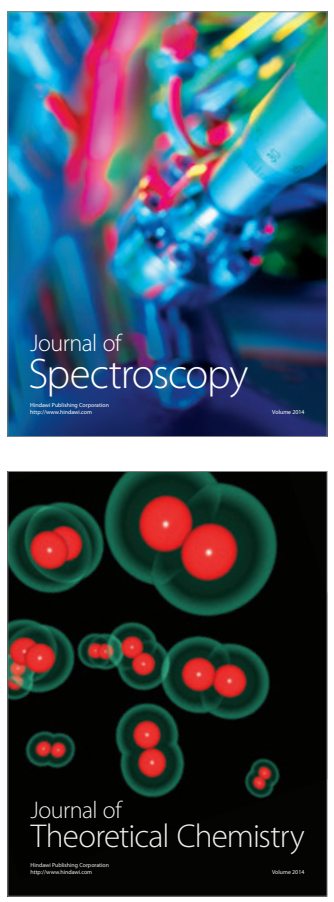
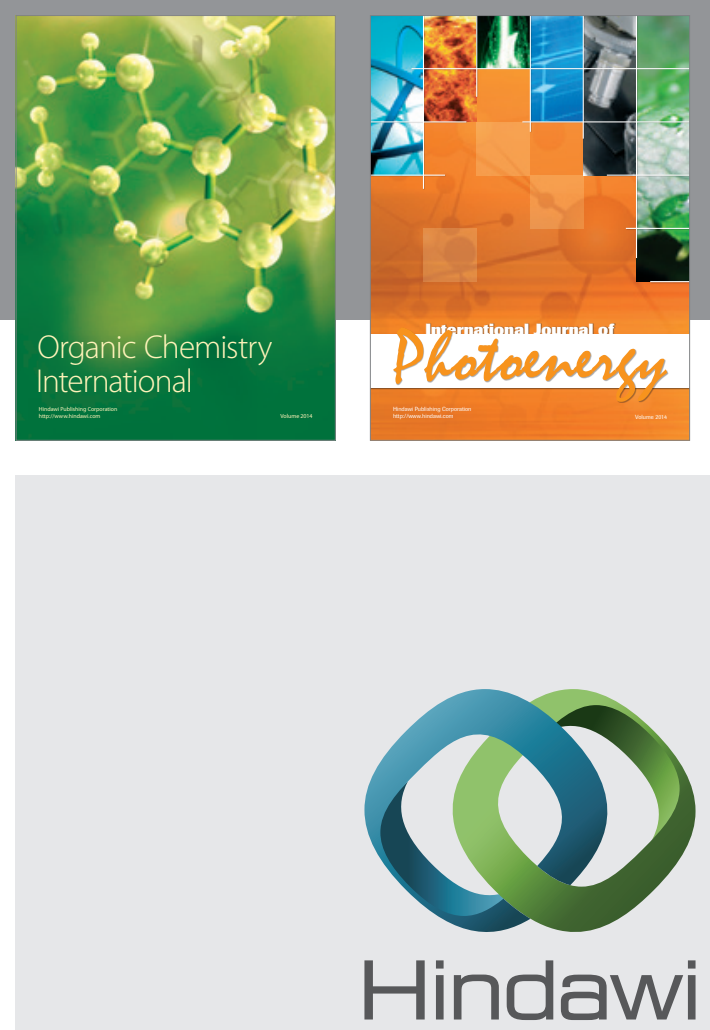

Submit your manuscripts at

http://www.hindawi.com
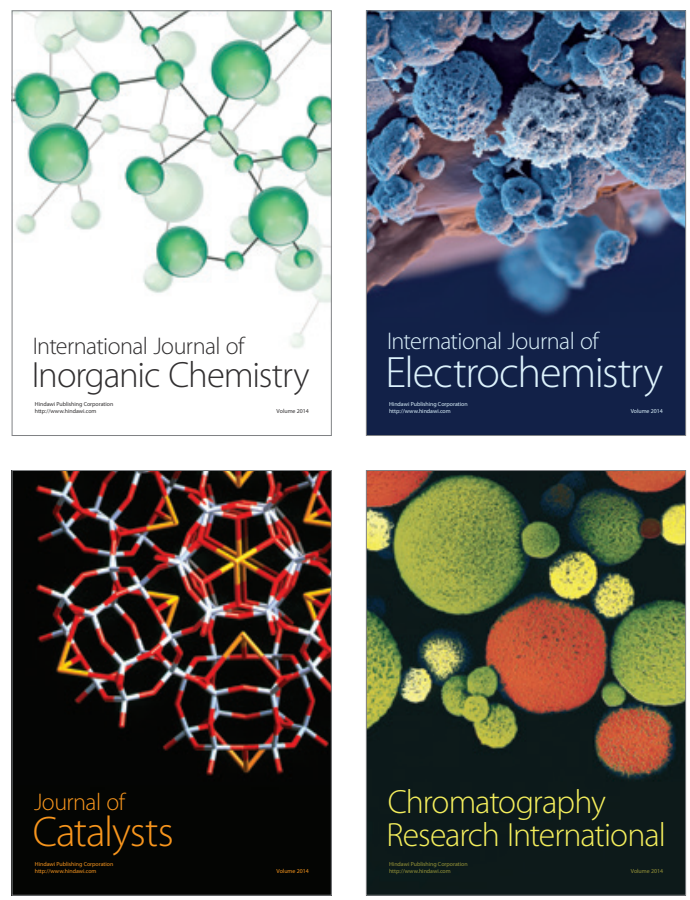
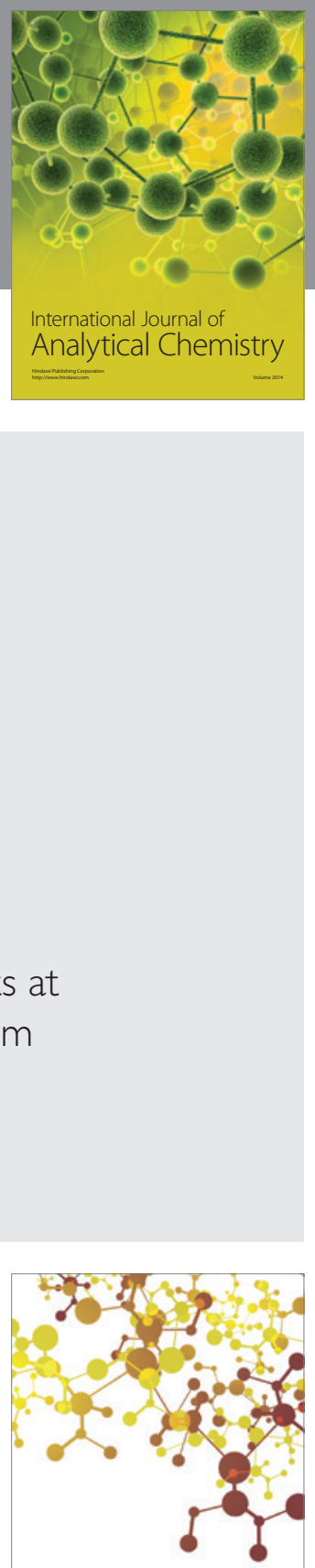

Journal of

Applied Chemistry
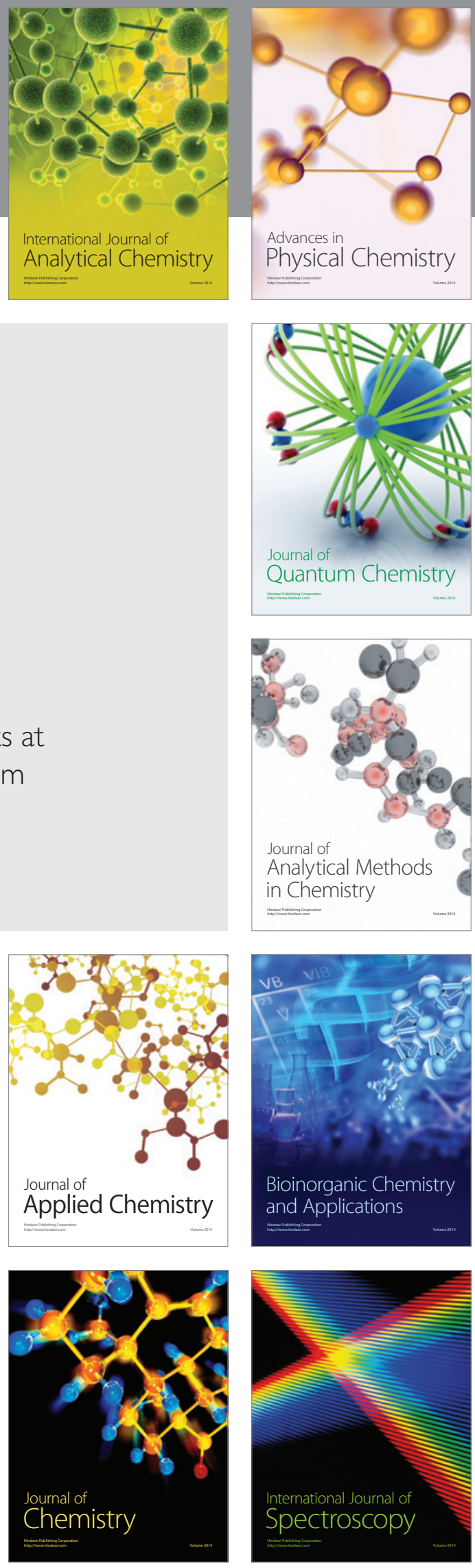